\title{
Aesthetic restoration using composite resin in teeth with inactive carious lesions: a conservative and predictable approach
}

\author{
Restabelecimento da estética com Resina composta em dentes com cárie \\ inativa: uma abordagem conservadora e previsivel
}

\author{
Patrícia DIAS1 iD https://orcid.org/0000-0001-5639-1686 \\ Nafaira Rízzea Ferreira SILVA ${ }^{1}$ iD https://orcid.org/0000-0002-2335-1327 \\ Victor da Mota MARTINS² iD https://orcid.org/0000-0001-6631-6161 \\ Paulo César de Freitas SANTOS-FILHO² ID https://orcid.org/0000-0003-3739-9003 \\ Uriel Paulo Coelho SILVA 1 iD https://orcid.org/0000-0003-0021-8336 \\ Camila Ferreira SILVA1 iD https://orcid.org/0000-0001-6419-6354
}

\section{ABSTRACT}

The importance of correct diagnosis, planning and treatment of dental spots is extremely important during aesthetic rehabilitation. Aesthetic requirements have become increasingly common in current society, and direct composite resin restorations are indicated due to the great advancement and increasing improvements of adhesive systems and composite resins. This work presents the clinical case of an oral aesthetic rehabilitation involving direct composite resin veneers associated with dental bleaching. The patient CSM, female, 21 years old, without systemic diseases, attended the dental clinic of the Morgana Potrich Eirelli College (FAMP) complaining of the unsatisfactory aesthetic appearance of her teeth. After careful anamnesis and detailed intraoral and extraoral examination, we identified the presence of a white spot on the upper anterior teeth. The spot was smooth and shiny, did not have soft tissue, and was well delimited and located in the cervical region. These characteristics led to the diagnosis of inactive carious lesions in the facial surface of the upper anterior teeth. After the treatment planning and its approval by the patient, the treatment started. The composite resin veneers associated with dental bleaching were indicated for better aesthetic results. The results achieved were satisfactory and met the patient's aesthetic requirements by means of a correct diagnosis, study, and adequate planning for the case.

Indexing terms: Composite resin. Dental veneers. Esthetics, dental.

\section{RESUMO}

A importância do correto diagnóstico, planejamento e tratamento das manchas dentárias é de suma importância durante uma reabilitação estética. As exigências estéticas têm se tornado cada vez mais recorrentes na sociedade atual e as restaurações diretas de resina composta são indicadas graças aos grandes avanços e crescente melhoramento dos sistemas adesivos e das resinas compostas. 0

$\operatorname{rrv}$

1 Faculdade Morgana Potrich, Curso de Odontologia. Av. Antônio Carlos Paniago, 65, Setor Mundinho, 75830-000, Mineiros, GO, Brasil. Correspondence to: CF SILVA. E-mail: <ferreirascamila@outlook.com>.

2 Universidade Federal de Uberlândia, Faculdade de Odontologia, Departamento de Dentística e Materiais Dentários. Uberlândia, MG, Brasil.

$\boldsymbol{\nabla} \boldsymbol{\nabla} \boldsymbol{V}$

How to cite this article

Dias P, Silva NRF, Martins VM, Santos- Filho PCF, Silva UPC, Silva CF. Aesthetic restoration using composite resin. RGO, Rev Gaúch Odontol. 2020;68:e20200052. http://dx.doi.org/10.1590/1981-863720200005220180101 
objetivo deste trabalho é relatar um caso clínico, onde foi realizado uma reabilitação oral estética envolvendo facetas diretas de resina composta associada ao clareamento dental. Paciente C. S. M do sexo feminino, 21 anos de idade, sem doenças sistêmicas, compareceu a clínica odontológica da Faculdade Morgana Potrich Eirelli (FAMP) queixando-se de estética insatisfatória nos dentes, após anamnese criteriosa, exame clínico intra e extra oral detalhados foi observado a presença de mancha branca nos dentes anteriores superiores, lisa, brilhante, sem a presença de tecido amolecido, bem delimitada e localizada na região cervical. Através dessas características e de uma anamenese criteriosa chegou-se ao diagnóstico de lesões de cárie inativa na vestibular dos dentes anteriores superiores. Após o planejamento e a aprovação da paciente, o tratamento iniciou-se, sendo indicado a confecção de facetas de resina composta associada ao clareamento dental para melhores resultados estético. Os resultados alcançados foram satisfatórios, atendendo as exigências estéticas e a satisfação da paciente, através de um correto diagnóstico, estudo e planejamento adequado para o caso.

Termos de indexação: Resinas compostas. Facetas dentárias. Estética dentária.

\section{INTRODUCTION}

Changes in tooth enamel are difficult to be diagnosed, because clinical characteristics are often very similar depending on the stage of the lesion. Among the different types of dental white spots, enamel hypoplasia, dental fluorosis, and amelogenesis imperfecta are directly related to disorders related to the development of active and inactive carious lesions [1].

The dental caries disease is a dynamic process in which the demineralization-remineralization process in the oral cavity is unbalanced, prevailing the demineralization of dental minerals. Changes related to this unbalanced process have a multi factorial etiology, so that host, microbiota, diet, and time are important determiners in the development and progression of the disease. These factors associated with a poor oral hygiene provoke the stagnation of biofilm on the teeth surface, which evolves to tooth decay. The demineralization process occurs due to the presence of acids. One of them is the lactic acid, which is produced by bacterial fermentation of carbohydrates, particularly sucrose. The sucrose adherence to the tooth surface lowers the $\mathrm{pH}$, which causes the dissolution of dental enamel and the transportation of calcium and phosphate to the oral environment $[2,3]$.

The best treatment depends on the diagnosis and the clinical characteristics of the white spot, such as intensity, severity degree, level of teeth damage, tooth wear, and treatment costs for the patient $[4,5]$.

Direct composite resin restorations are indicated due to the great advances and increasing improvements of adhesive systems and composite resins. The main advantages of this type of rehabilitation are the easy repair procedure, easy execution, function and aesthetic restoration, and the highly conservative nature of this treatment, as little tooth structure is removed $[6,7]$.
This article presents a clinical case report in which a patient reported to be unsatisfied with the appearance of her upper anterior teeth, where we diagnosed the presence of inactive carious lesions. The treatment chosen was direct composite resin restoration.

\section{CASE REPORT}

The patient CSM, female, 21 years old, without systemic diseases, attended the dental clinic of the Morgana Potrich Eirelli College (FAMP) complaining she was unsatisfied with the appearance of her teeth. After careful anamnesis and detailed intra oral and extraoral examination, we found white spots on the upper anterior teeth that were smooth, shiny, without soft tissue, well delimited and located in the cervical region. Based on these characteristics, on a careful anamnesis, and on a visual-tactile examination, the spots were diagnosed as inactive carious lesions in the facial surface of the upper anterior teeth (figure 1). After the diagnosis, a meticulous treatment planning was designed. The treatment included direct composite resin restorations associated with dental bleaching, because, after the remineralization of the white spot, the clinical aspect still had a bad aesthetic quality, which was the patient's main complaint. This research began only after the patient signed the Informed Consent (Annex 1).

In order to obtain a dental substrate with a satisfactory color and better aesthetic results, we indicated
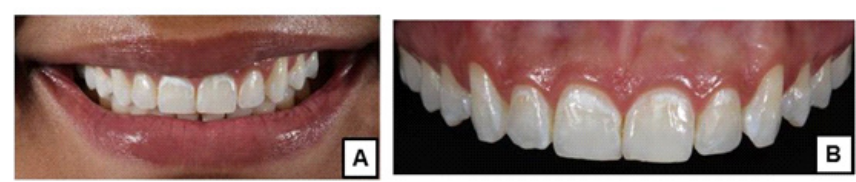

Figure 1. A and B) Initial aspects of carious lesions. 254×190mm (96 x 96 DPI). 
in-office dental bleaching from the second premolar to the other second premolar of the upper and lower dental arch. The dental bleaching followed the following steps: pumice and water prophylaxis with a Robinson brush and a rubber cup; Top Dam (FGM) gingival barrier application; then, desensitizing (Desensibilize KF 2\% FGM) application on the teeth that would be bleached and removal after ten minutes; following the manufacturer's guidelines, hydrogen peroxide and thickener were mixed in the proportion 3:1 (Whiteness HP Max 35\% - FGM) and applied in the whole tooth, but in the lingual surface, using a regular microbrush (KG); it was applied twice for ten minutes. This procedure was repeated thrice with a 7-day interval (figure 2). In order to soften the white spots, microabrasion sessions were carried out, however, they did not present successful results due to the depth of the spots. Dental caries are diagnosed according to their current stage. Zetaplus condensation silicone was used to make the cast models of the upper and lower arches. The intercondylar relation was registered with a face-bow and a bite fork to mount the models on a semi-adjustable articulator (SAA) at maximum habitual intercuspation (MHI). The SAA, the records, and casts were sent to a laboratory for the preparation of a diagnostic wax-up of the upper anterior teeth, so that the patient and the dentist team could approve the treatment after the evaluation of the patient's occlusion, laterality, and protrusion. Then, after some adjustments, the waxed cast was used to build up the silicone index (figure 3 ).
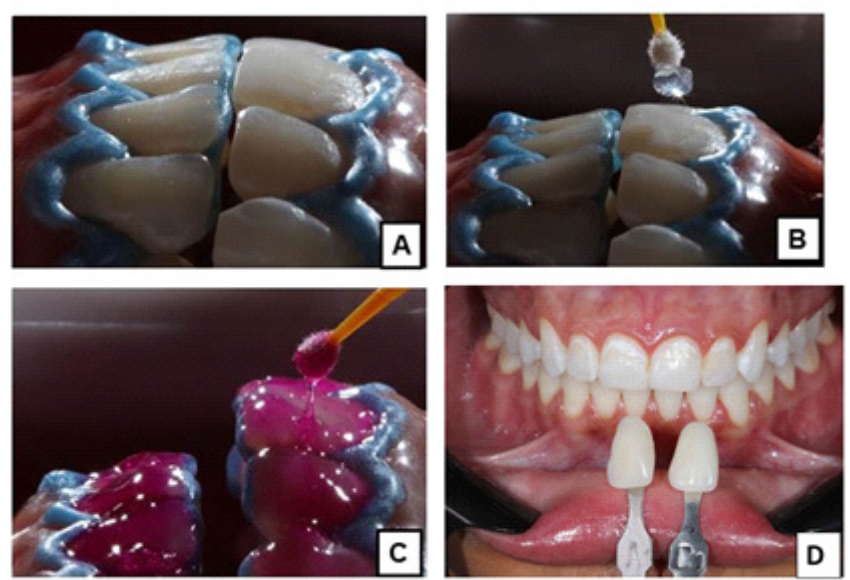

Figure 2. Dental bleaching. A) Application of desensitizing for 10 minutes B) Application of the Top Dam gingival barrier. C) Application of tooth whitening gel (hydrogen peroxide 35\%). D) Final result after microabrasion and end of the bleaching process. 338x190mm (96 x 96 DPI).
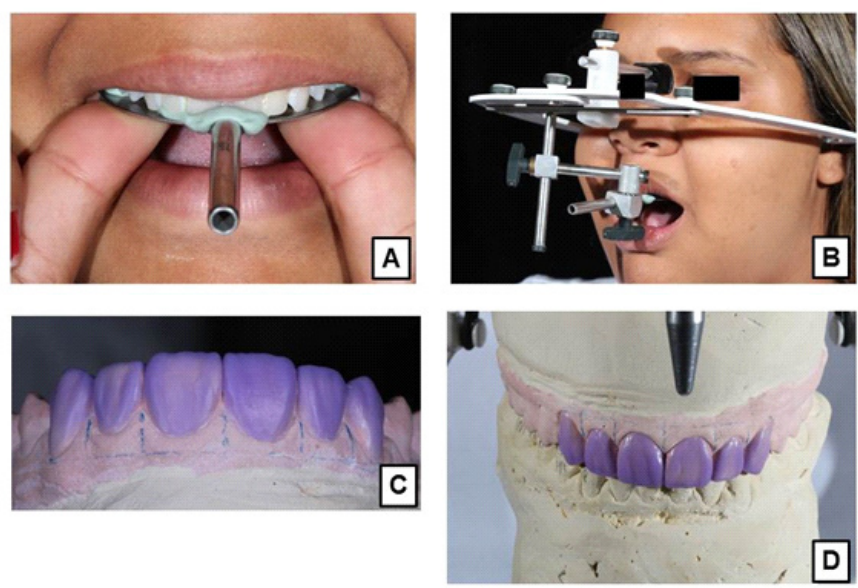

Figure 3. Model mounting in semi-adjustable articulator (SAA) and diagnostic wax-up. A and B) Registration of the intercondylar relation. C) Model mounting in SAA. D) Diagnostic wax-up. 254x190mm (96 x 96 DPI).

Vita Classical Shade Guide was used to choose the shade of the composite resins to be used in the veneers. The shade chosen was B1. The silicone index was build up by means of the diagnostic wax-up, which was used as a guide during the restoration process (figure 4).
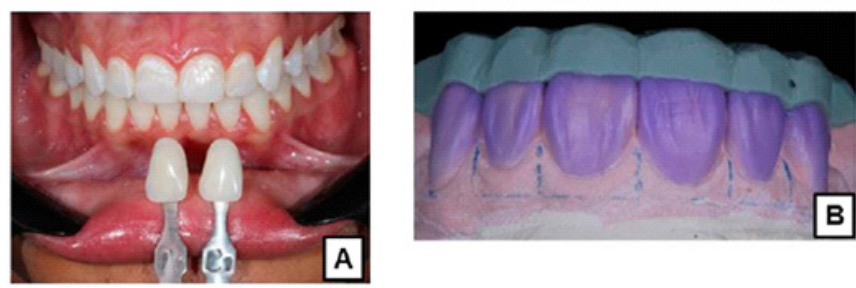

Figure 4. A) Shade selection. B) Silicone index. 254x190mm (96 x 96 DPI).

Moisture was controlled by (modified) absolute isolation of the operating field, aiming to retract gingival tissues, keeping the oral environment dry, having a better visibility of the operating field, protecting the patient against aspiring or swallowing instruments, and reducing the treatment time. The white spots were removed by using high-speed rotating diamond burs 1012 (KG-SORENSEN). Then, teeth were prepared for veneers using polishing diamond burs by means of a minimally invasive technique, i.e. a technique that causes little tooth wear. This wear was carried out after the restorative test, where we observed that using resin to cover the white spots without wearing the teeth did not cover the spots properly. 
The restoration procedure followed the following clinical protocol: insertion of a 000 Maquira retractor cord; all surfaces of the teeth were etched with phosphoric acid 37\% (Condac - FGM) for 30 seconds; washing with a high-pressure water and air spray for one minute for neutralization; moisture control using absorbent paper; application of a Single Bonde (3M) adhesive: the first layer was applied in the whole tooth, with a 20-second interval for solvent evaporation, then the second layer was applied to photopolymerize each tooth for 20 seconds; application of enamel composite resin (3M Z350 XT, shade $\mathrm{XWE}$ ) in the silicone index, positioning it near the mouth and photopolymerizing each tooth for 20 seconds; that is how the palatal shell was built; increment insertion up to two millimeters of dentin composite resin on the whole facial surface, followed by mamelons building-up (3M Z350 XT, shade WD) and enamel resin application (3M
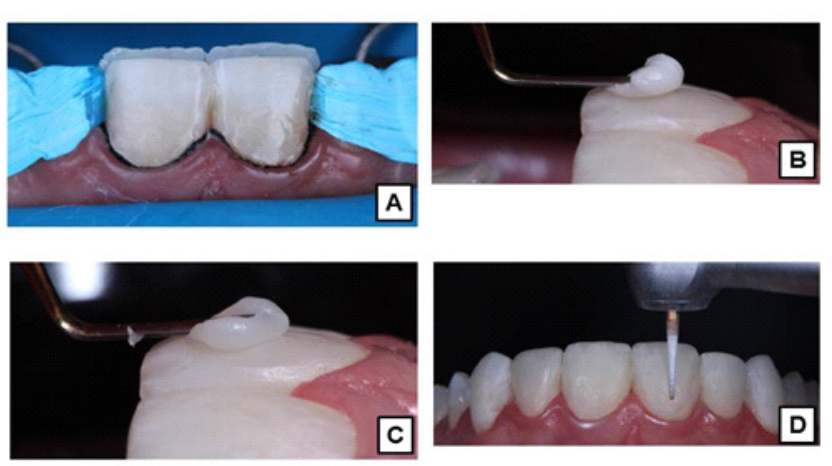

Figure 5. Restoration and Finishing. A) Palatal shell build-up B) Increments of enamel composite resin. C) Increments of dentin composite resin. D) Finishing with finishing burs and serrated metal strip. 254x190mm $(96 \times 96 \mathrm{DPI})$.
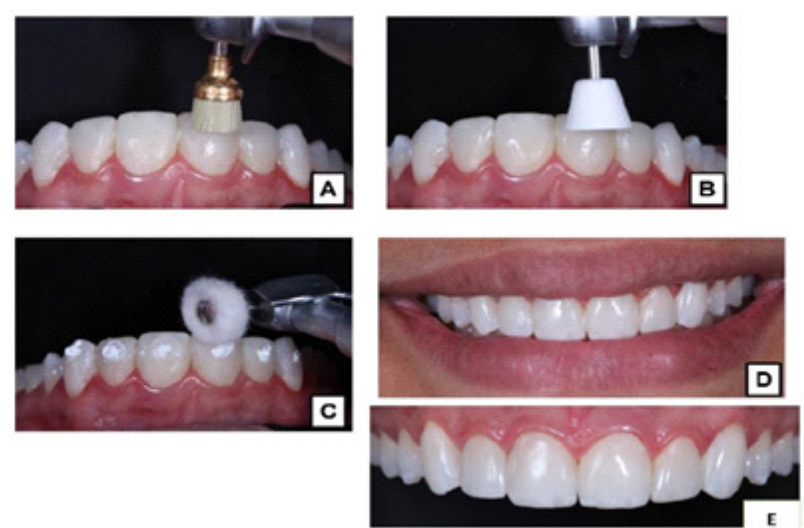

Figure 6. Tooth Polishing. A) Jiffy Polisher cups for composite resin. B) Astrobrush Polisher made of silicon carbide. Polishing with felt discs and polishing paste. D-E) Final result. 338×190mm (96 x 96 DPI).
Z350 XT, shade XWE) on the facial surface of teeth. The occlusal adjustment was performed using high-speed rotating diamond burs, and finishing was performed using polishing diamond burs, a Sof-Lex Goiaba disc (3M), and a serrated metal strip (TDV) for proximal surfaces (figure 5). The polishing process of all teeth was performed using Jiffy Polisher cups (Ultradent), a cup-shaped Astrobrush polisher (Ivoclar) and felt discs (TDV) with an Enamelize paste (figure 6).

\section{DISCUSSION}

The diagnosis was made after a detailed anamnesis and based on the clinical characteristics and etiological factors of dental changes. There are complementary methods for diagnosis, but until this moment, the visual method is the gold standard for diagnosis; therefore, it was used in this study $[8,9]$.

In order to carry out an efficient visual exam, Conceicao [8] and McCOMB [10] recommended conducting prophylaxis, drying the tooth surface with air jet, and having good lighting in the environment for diagnosis. The tactile examination is performed with an exploratory probe, which is used by dental surgeons who consider it a reliable method. According to McCOMB [10], the exploratory probe may cause damage to the tooth surface and should be used with caution or should not be used whatsoever on occlusal surfaces. In the study case, the white spots were diagnosed as multiple inactive carious lesions. They were smooth, shiny, did not have soft tissues and were well delimited.

Considering that the lesions were inactive and the white spots bothered the patient, a treatment plan was formulated. The treatment included the use of direct composite resin restoration and dental bleaching. Dental bleaching is an auxiliary method frequently used in minimally invasive aesthetic restorations, in which there is little tooth wear. This procedure aims to obtain a satisfactory aesthetic result both in tooth shade and lesion delimitation [11-13]. This method was used in the study case to obtain a substrate with a satisfactory color for aesthetic rehabilitation, and because the patient wanted to have whiter teeth.

Diagnostic wax-ups have been used by dental surgeons as a complementary diagnostic method for aesthetic restorations [14,15]. Kahng [14] states that 
diagnostic wax-ups aim to reconstruct worn teeth and determine the plane of occlusion and the anterior index. Moslehifard [15] stated that diagnostic wax-ups guide the demonstration of the clinic case for the patient and allows the prediction of occlusal stability and freedom of mandibular movements, which are directly associated with the stomatognathic system balance.

Araújo [16] and Baratieri [17] stated that the silicone index helps to control tooth shape in the execution of the restoration treatment, which reduces the treatment time and determines dental anatomical contours that should be copied from the diagnostic wax-up. In this study case, the silicone index was extremely important to provide greater stability during the restorative technique.

The search for minimally invasive aesthetic restorations has increased every day in dental clinics, and surgeons have often had difficulties in choosing the composite resin. For this choice, dental surgeons should evaluate each patient and the characteristics of each resin [18-19]. The resin Filtek Supreme (3M) has a resin restorative material incorporated into nanotechnology with the combination of nanoparticles and nanoclusters. The combination of these two particles results in a nanoparticulate resin with the same polishing of a microparticulate resin and the same resistance of a hybrid resin [20-22]. Likewise the physical characteristics of the composite resins, optical characteristics are of great relevance during a restorative procedure, such as color, translucency, opalescence, and fluorescence, which are determining factors in the stratification and mimicry of the dental structure [21].

The stratification technique is used to obtain aesthetic restorations with a color similar to the natural color of the tooth. This technique consists in using several increments of composite resins with different values on the tooth that will be restored. It is necessary to know how and where to use each increment. For dentin, it is necessary to have knowledge on hue, chroma, and shape in order to simulate the effect of opalescence and have a fluorescence similar to that of a natural tooth. Finally, it is necessary to adjust the value or lightness and remake the specific details of the natural teeth [22].

The finishing and polishing process is key for a successful aesthetic restoration. It is conducted after the occlusal adjustment with a finely granulated diamond bur or a carbide cone-shaped drill bit with multiple blades, and
Sof-Lex discs to correct the restoration shape. The finishing and polishing of the proximal surfaces was performed with dental abrasive strips of different granulations. After that, silicon burs were used to start the polishing process. Felt discs and ultra-thin discs associated with a polishing paste were used to give brightness to the restoration surface [23].

In view of the good mimetic and aesthetic results, we concluded that the composite resin could be used in several clinical cases, such as in aesthetic restoration of white spots, as reported in this paper. The knowledge of material properties, limitations and indications is essential for a correct application of the material used.

\section{CONCLUSION}

White spots on teeth are not considered a good aesthetic standard; for this reason, patients who have them look for dental professionals for proper treatment.

Choosing the most appropriate treatment will depend on the precise diagnosis of the white spot lesion and its clinical characteristics. Among the several aesthetic treatments available, the use of direct composite resin veneers is an excellent option, since it promotes a harmonic, high-level aesthetic smile if correctly performed, and it satisfactorily restores teeth functions and aesthetics by means of a conservative and predictable approach.

\section{Collaborators}

P DIAS, and NRF SILVA contributed to the realization of the clinical case, accompanying and processing the entire process from planning to finalizing the case. They also contributed to the discussion and conclusion of this article through articles by research articles on the subject. VM MARTINS and PCF SANTOSFILHO were the authors responsible for revising and correcting the content. UPC SILVA was the author and professor responsible for monitoring the execution of the clinical part, taking photographs and contributing to the discussion of the article. CF SILVA was the mentor responsible for the choice and theme of the title, indication of authors and articles, review and correction of the content, structuring and formatting of all the work.

\section{REFERENCES}

1. Shafer WG, Hine MK, Levy BM. Distúrbios do desenvolvimento das estruturas bucais e parabucais. in: tratado de patologia bucal. 4a . ed. Rio de Janeiro: Guanabara Koogan; 987. 
2. Pereira, AC. Saúde coletiva: métodos preventivos para doenças bucais. São Paulo: Artes Médicas; 2013.

3. Maltz M. Cariologia: conceitos básicos, diagnósticos e tratamento não restaurador. São Paulo: Artes Médicas; 2016.

4. Peruchi CMS, Barreto TDP, Silva LE. O uso da microabrasão do esmalte para remoção de mancha branca sugestiva de fluorose dentária: caso clínico. Rev Odontol Arac. 2004;25(2):72-77.

5. Pithan JCA, Malmann A, Pithan AS, Costa CC. Amelogênese imperfeita: revisão de literatura e relato de caso clínico. Rev ABO de Nac. 2002;10(2):88-92.

6. Maragoni MH, Carvalho RM. Dentística cosmética: em hipoplasia de esmalte. RGO, Rev Gaúch Odontol. 1992;40(5):344-45.

7. Soares CJ, Fonseca RB, Martins LR, Giannini M. Esthetic rehabilitation of anterior teeth affected by enamel hypoplasia: a case report. J Esthet Restor Dent. 2002;14(6):340-348. http://dx.doi.org/10.1111/j.1708-8240.2002.tb00176.x

8. Conceição EN. Dentística saúde e estética. $2^{a}$ ed. Porto Alegre: Artemed; 2007.

9. Santos NB, Forte FDS, Moimaz SAS, Saliba NA. Diagnóstico de cárie hoje: novas tendências e métodos. J Bras Odontopediatr Odontol Bebê. 2003;6(31):255-262.

10. McComb D, Tam LE. Diagnosis of occlusal caries: Part I. Conventional methods. J Can Dent Assoc. 2001;67(8):454-457.

11. Rodrigues RB, Veríssimo C, Pereira RD, Queiroz CL, Novais VR, Soares CJ, et al. Clareamento dentário associado à facetas indiretas em cerâmica: abordagem minimamente invasiva. Rev Odontol Bras Central. 2012;21(59): 520-525.

12. Chaves VSF, Torres LMS, Chaves LVF, Cunha CTM. Recontorno cosmético associado à clareação dentária: relato de caso clínico. Uniciências. 2015;19(2):150-154. http://dx.doi. org/10.17921/1415-5141.2015v19n2p\%25p

13. Alves $M$, Junqueira $A$, Rehder Neto FC. Tratamento de manchas brancas: Diagnóstico e tecnologia associados ao planejamento estético. Rev APCD Estét. 2012;01(1):28-43.

14. Kahng LS. Patient-dentist-technician communication within the dental team: using a colored treatment plan wax-up. J
Esthet Restor Dent. 2006;18(4):185-195. http://dx.doi.org/10. 1111/j.1708-8240.2006.00017.x.

15. Moslehifard E, Nikzad S, Geraminpanah F, Mahboub F. Fullmouth rehabilitation of a patient with severely worn dentition and uneven occlusal plane: a clinical report. J Prosthodont. 2012;21(1):56-64. http://dx.doi.org/10.1111/j.1532-849X.20 11.00765.x

16. Araújo, EP, Rocha Filho LA, Brum GT, Caldo Teixeira AS. Fechamento de diastemas com restaurações diretas de resina composta: relato de caso clínico. Rev Gest Saúde. 2009;1(3):33-38.

17. Baratieri LN, Monteiro Júnior S, Correa M, Ritter AV. Posterior resin composite restorations: a new technique. Quintessence Int. 1996;27(11):733-738.

18. Goldstein MB. Rapid-fire posterior resins. The unwritten ... taking advantage of nanocomposite technology. Dent Today. 2004;23(3):60-65

19. Andrade VA, Oliveira LGF, Menezes Filho PF, Silva CHV. Tendências das resinas compostas nanoparticuladas. Int J Dent. 2009;8(2):153-157.

20. Conceição EN. O potencial dos compósitos directos em dentes anteriores. In: Conceição EN. Restaurações estéticas - compósitos, cerâmicas e implantes. Porto Alegre: Artmed; 2005. p. 145-173.

21. Davis N. A nanotechnology composite. Compend Contin Educ Dent. 2003;24(9):662-670.

22. Duke ES. Has dentistry moved into the nanotechnology era?. Compend Contin Educ Dent. 2003;24(5):380-382.

23. Soares CJ, Fonseca RB, Martins LR, Giannini M. Esthetic rehabilitation of anterior teeth affected by enamel hypoplasia: a case report. J Esthet Restor Dent. 2002;14(6):340-348. http://dx.doi.org/doi:10.1111/j.1708-8240.2002.tb00176.x

Received on: 13/12/2018

Final version resubmitted on: 21/5/2019

Approved on: 23/6/2019 